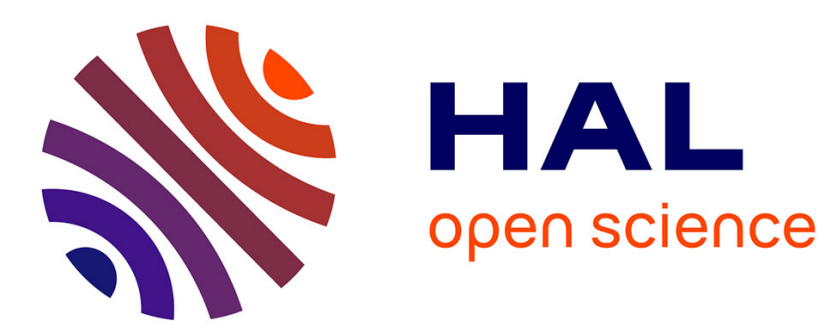

\title{
Unravelling the Origin of the Yellow-Orange Luminescence in Natural and Synthetic Scapolites
}

Féodor Blumentritt, Camille Latouche, Yann Morizet, Maria-Teresa Caldes, Stéphane Jobic, Emmanuel Fritsch

\section{- To cite this version:}

Féodor Blumentritt, Camille Latouche, Yann Morizet, Maria-Teresa Caldes, Stéphane Jobic, et al.. Unravelling the Origin of the Yellow-Orange Luminescence in Natural and Synthetic Scapolites. Journal of Physical Chemistry Letters, 2020, 11 (12), pp.4591. hal-03022208

\section{HAL Id: hal-03022208 \\ https://hal.science/hal-03022208}

Submitted on 24 Nov 2020

HAL is a multi-disciplinary open access archive for the deposit and dissemination of scientific research documents, whether they are published or not. The documents may come from teaching and research institutions in France or abroad, or from public or private research centers.
L'archive ouverte pluridisciplinaire HAL, est destinée au dépôt et à la diffusion de documents scientifiques de niveau recherche, publiés ou non, émanant des établissements d'enseignement et de recherche français ou étrangers, des laboratoires publics ou privés. 


\title{
UNRAVELLING THE ORIGIN OF THE
}

\section{YELLOW-ORANGE LUMINESCENCE IN}

\section{NATURAL AND SYNTHETIC SCAPOLITES}

Féodor Blumentritt ${ }^{a}$, Camille Latouche ${ }^{a}$, Yann Morizet ${ }^{a, b}$, Maria-Teresa Caldes ${ }^{a}$, Stéphane Jobic $^{a}$ and Emmanuel Fritsch ${ }^{a *}$

${ }^{a}$ Université de Nantes, CNRS, Institut des Matériaux Jean Rouxel, IMN, F-44000 Nantes, France

${ }^{b}$ Université de Nantes, Nantes Atlantique Universités, Laboratoire de Planétologie et Géodynamique (LPG), UMR CNRS 6112, 2 rue de la Houssinière, 44322 Nantes Cedex, France.

\section{Corresponding Author}

*Emmanuel.fritsch@cnrs-imn.fr

\begin{abstract}
After decades of speculation without material proof, the yellow-orange luminescence of scapolite is definitely assigned to $\left(\mathrm{S}_{2}\right)^{-}$activators trapped in $\left[\mathrm{Na}_{4}\right]$ square cages. Synthetic sulfur-doped scapolites confirm the implication of sulfur species in luminescence. Formally, the emission and excitation spectra of various polysulfide species were calculated. The excellent match between theory and experiments for $\left(\mathrm{S}_{2}\right)^{-}$dimers provide definitive proofs that it is the cause of the yelloworange luminescence in scapolite.
\end{abstract}




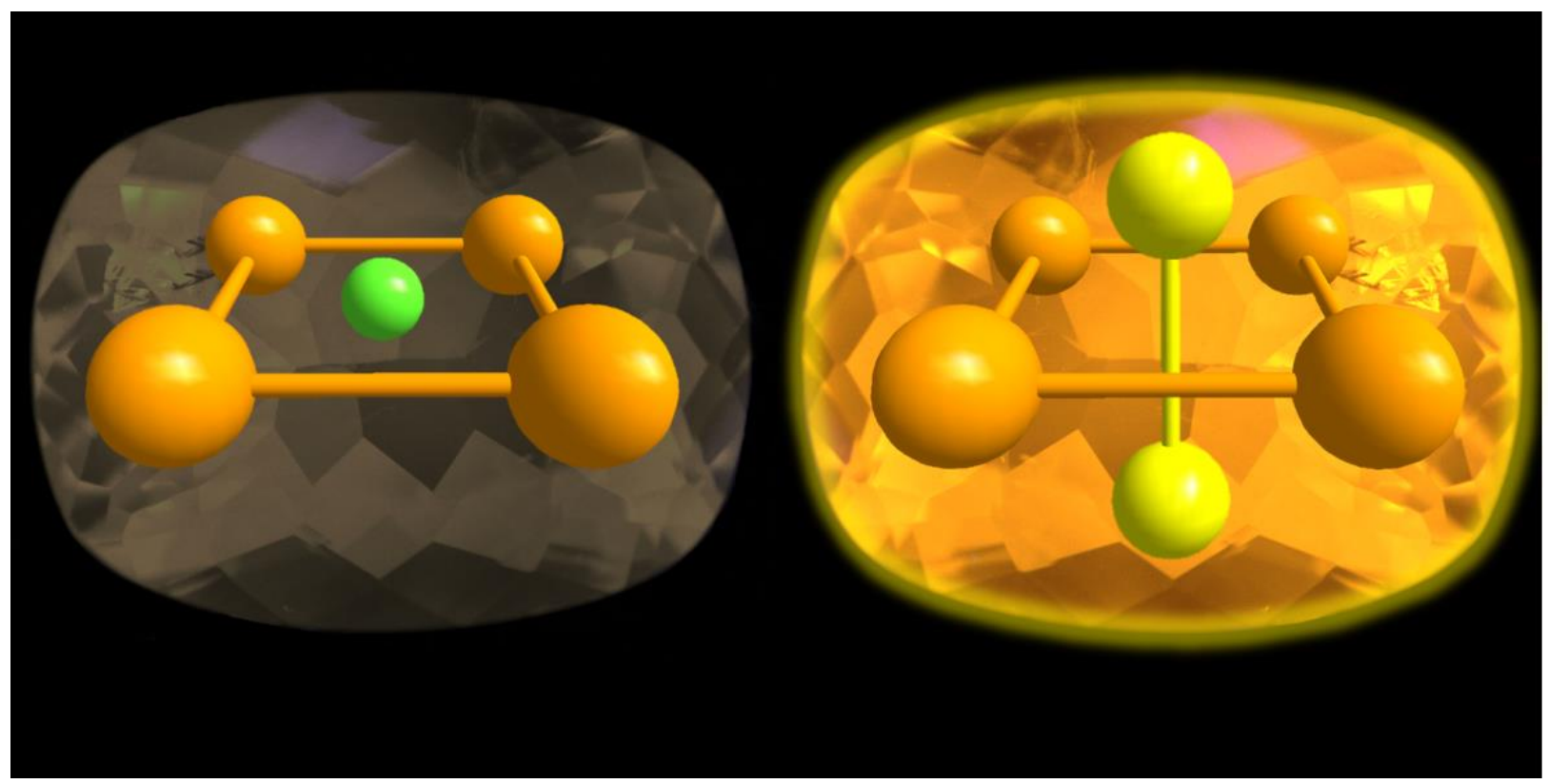

KEYWORDS: scapolite, $\left(\mathrm{S}_{2}\right)^{-}$activator, luminescence spectrum, vibronic coupling, DFT

By analogy with bio-mimetism, mineralo-mimetism can be defined as an analytic process consisting in the synthesis of innovative materials with desired physical or chemical properties inspired from natural minerals with potential anthropic applications. ${ }^{1}$ In this context, a number of interesting optical (but not only) properties have been identified over time in natural minerals that could indeed find a use in industry if adequately synthetized. Examples include optical diffraction of opals, ${ }^{2}$ cathodoluminescence of sodalite, ${ }^{3}$ thermoluminescence and triboluminescence of fluorite, ${ }^{4-6}$ or photochromism of hackmanites, ${ }^{7}$ this latter potentially opening the door for optical storage. ${ }^{7-10}$ Here we focus specifically on the emission under UV excitation of scapolite, a rockforming mineral with recently discovered photochromic properties ${ }^{11}$. Thus, demonstrating 
unambiguously the origin of the yellow-orange luminescence of scapolite and reproducing it may be helpful to produce a new luminescent and also, possibly, photochromic material.

So far, the yellow orange luminescence of scapolite, ${ }^{12,13}$ sodalite ${ }^{10,14-16}$ and tugtupite ${ }^{17}$ has been ascribed to $\left(\mathrm{S}_{2}\right)^{-}$polyanions without any formal proof. The presence of the same isolated anionic groups is also suspected to account for the emission of other aluminosilicates (zeolites ${ }^{18}$ ) and alkali halides ${ }^{13,19-23}$. The aim of this study is to provide a definite proof that the cause of the luminescence is indeed single charged sulfur dimers by combining experimental and theoretical approaches.

Scapolite is a well-known mineral family forming a solid solution between meionite and marialite with the archetype $\left(\mathrm{Ca}_{4} \mathrm{Al}_{6} \mathrm{Si}_{6} \mathrm{O}_{24} \mathrm{CO}_{3}\right)$ and $\left(\mathrm{Na}_{4} \mathrm{Al}_{3} \mathrm{Si}_{9} \mathrm{O}_{24} \mathrm{Cl}\right)$ formulations. ${ }^{24}$ Both compounds are reported as crystallizing in the $\mathrm{I} / \mathrm{m}$ space group. ${ }^{25,26}$ Namely, the aluminosilicate framework of scapolite is constructed from rings of four tetrahedra (Fig. 1a). These rings are stacked along the $c$-axis and connected to each other by four units of two edge-sharing tetrahedra pillars to form infinite ${ }^{1} / \infty\left[(\mathrm{Al}, \mathrm{Si})_{12} \mathrm{O}_{24}\right]$ ribbons $(\mathbf{F i g} . \mathbf{1 b})$. These ribbons condense to give rise to a 3D structure with oblong and square tunnels (Fig. 1c) that host alkali or alkaline earth atoms and chlorine atoms or carbonate groups, respectively. In marialite species, chlorine atoms are located at the centre of $\left[\mathrm{Na}_{4}\right]$ squares (Fig. 1d). 


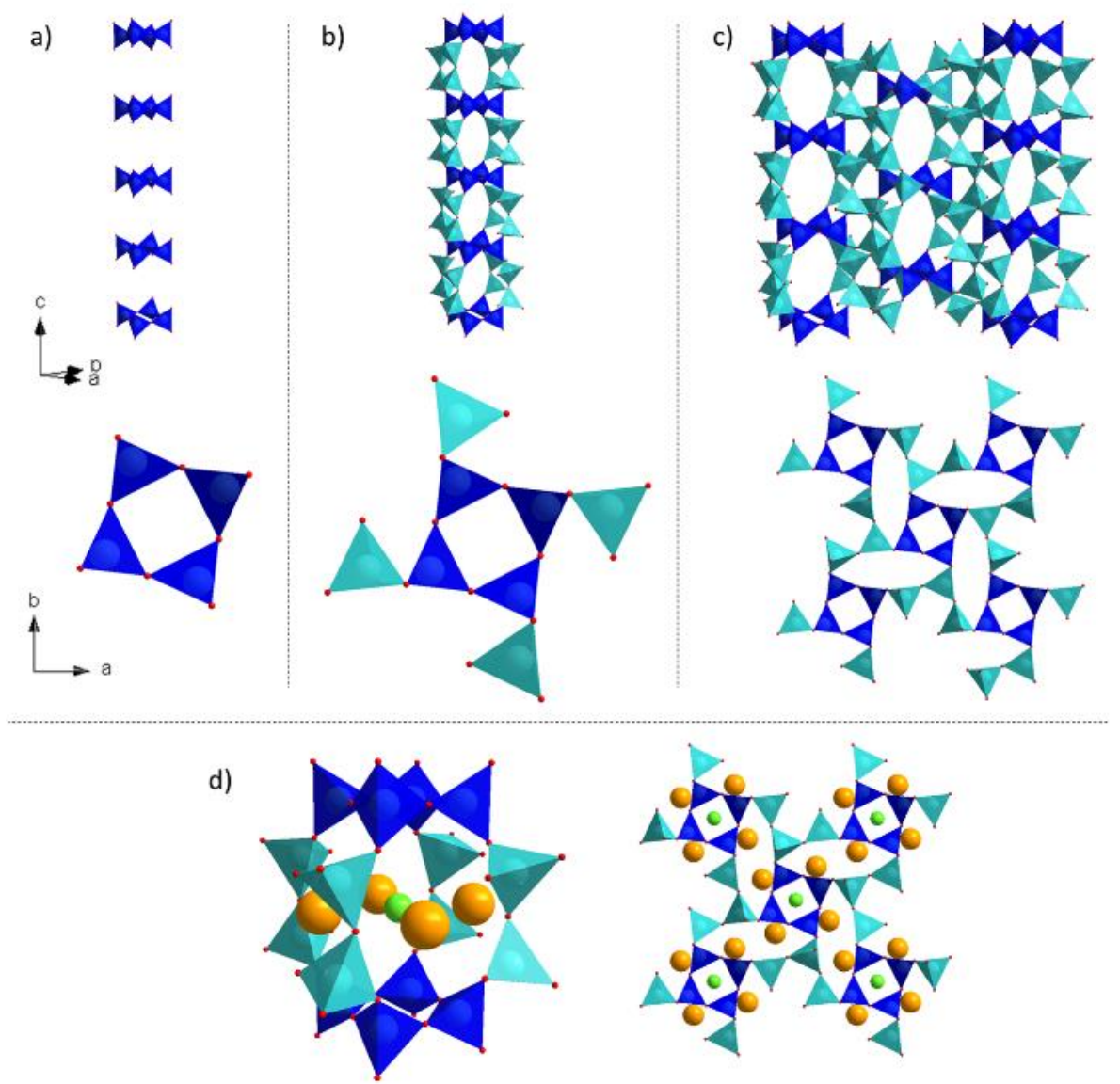

Fig. 1. Details of marialite structure with a) the stacking of rings of four tetrahedra along the caxis, b) ribbons of infinite $\left[(\mathrm{Al}, \mathrm{Si})_{12} \mathrm{O}_{24}\right]$ units, c) condensed ribbons defining the aluminosilicate skeleton and d) filling of cavities by alkali or alkali earth cations (orange) and chlorine or carbonate anions (green). According to Sokolova et $a l .{ }^{27}$, dark blue tetrahedra would be fully occupied by $\mathrm{Si}^{4+}$ while light blue tetrahedra would be a mixed site between $\mathrm{Si}^{4+}$ and $\mathrm{Al}^{3+}$.

The luminescence in scapolite was described in 1930s with a remarkable vibronic structure revealed even at room temperature. ${ }^{28,29}$ In 1964 , a strong resemblance with luminescence spectra of alkali halides (e.g. $\mathrm{NaBr}$ and $\mathrm{KBr})$ containing $\left(\mathrm{O}_{2}\right)^{-}$centers was noticed for intentionally $\mathrm{S}$ doped materials. Similar-looking emission in alkali halides is then assigned by analogy to $\left(\mathrm{S}_{2}\right)^{-}$species deemed to exhibit similar (but energy shifted) characteristics. ${ }^{13}$ This assumption was further substantiated, however without proved when scapolites annealed in presence of sulfate and sulfite 
revealed an increase of the luminescence probably caused by reduction of these molecular ions into $\left(\mathrm{S}_{2}\right)^{-15} \cdot{ }^{-1}$ In an attempt to determine the location of $\left(\mathrm{S}_{2}\right)^{-}$within the scapolite structure, one single set of electron paramagnetic resonance analyses concluded that the S-S pairs would lie along the diagonal of the previously described $\mathrm{Na}_{4}$ square planes which turns out to be incorrect (see $\mathrm{SI}$ ). ${ }^{30}$ Burgner gave in 1978 the first precise description of the vibronic structure at low temperature $(4.2 \mathrm{~K})$ and suggested that $\left(\mathrm{S}_{2}\right)^{-}$species were in quite good agreement with simple harmonic oscillator calculation only building on an initial assumption. ${ }^{12}$ In parallel, investigations conducted on luminescent sodalites ${ }^{15}$ concluded that the vibronic structure corresponds to single charged $\left(\mathrm{S}_{2}\right)$ dimers elongation mode. Then, due to the fact that scapolite and sodalite are aluminosilicates with cages that can trap $\left(\mathrm{S}_{2}\right)$ dimers, it was tempting to associate the same center to the related emission in scapolite.

However, once again, conclusions were limited to analogies with other, very different materials, doubts remain on the exact species of the emitting center and no definitive proof has ever been proposed. In addition some scapolites are also reported as photochromic materials, ${ }^{11}$ with a reversible color change from colorless to deep blue under UV-excitation (e.g. $\lambda_{\text {exc }}=254 \mathrm{~nm}$ ). The origin of this property is often related to the presence of $\left(\mathrm{S}_{2}\right)^{-}$centers by comparison with other aluminosilicates (sodalite, tugtupite, ... $)^{31,32}$ in which yellow-orange luminescence is also observed with similar characteristics. ${ }^{33}$ Hence, unravelling the origin of the luminescence in scapolite could be an indirect progress in the study of its photochromism. In that context, we embarked on the elucidation of the luminescence property observed in natural gems and synthetic $\mathrm{Na}_{4} \mathrm{Al}_{3} \mathrm{Si}_{9} \mathrm{O}_{24} \mathrm{Cl}: \mathrm{S}$ powdered materials. They were prepared following Almeida et al. ${ }^{34}$ protocol; namely, $\mathrm{SiO}_{2}$ (Alfa Aesar, $99.8 \%$ ), $\mathrm{Al}_{2} \mathrm{O}_{3}$ (Fluka, p.a.), $\mathrm{Na}_{2} \mathrm{O}$ issued from decarbonatation $\left(900^{\circ} \mathrm{C}\right.$, air, $15 \mathrm{~min}$ ) of $\mathrm{Na}_{2} \mathrm{CO}_{3}$ (Prolabo, 99.5\%), $\mathrm{NaCl}$ (Alfa Aesar, 99.999\%) and $\mathrm{Na}_{2} \mathrm{~S}$ (Sigma-Aldrich, 
$>97 \%$ ) were mixed together in the 18:3:3:4:0 (no S doping) and 18:3:3:1.6:0.2 (0.24 at\% S-doped material) molar ratio for samples hereafter labeled P1 and P2, respectively. Synthetic scapolites were prepared under high pressure $(1.5 \mathrm{GPa})$ and high temperature $\left(975^{\circ} \mathrm{C}\right)$ for $48 \mathrm{~h}$ following the method described by Morizet et al. ${ }^{35}$ The return to ambient conditions was carried out by cuttingoff the electric power and doing an isobaric quench. Sulfur was introduced in small amounts (i.e. 0.24 at $\%)$ to avoid moving out of the stability field of marialite. From the refinement of the X-ray diffraction patterns of samples P1 and P2, scapolite (marialite) was systematically observed with concentrations up to $60 \mathrm{wt} \%$. Impurities were $\mathrm{SiO}_{2}, \mathrm{Al}_{2} \mathrm{O}_{3}, \mathrm{NaCl}$ unreacted precursors, and $\mathrm{NaAlO}_{2}$ and $\mathrm{NaAlSi}_{3} \mathrm{O}_{8}$ sub-products. A natural sample $\mathrm{N} 1$ was considered as representative of a batch of ten Afghan gems. EDX analyses of N1 yielded the following atomic percentages: Na:9.19, Ca:0.35, K:1.13, Al:7.95, Si:23.17, O:55.15, Cl:2.61, S:0.45. These are very close to the expected marialite composition. Room temperature luminescence spectra of N1, P1 and P2 excited at 390 nm are gathered in Fig. 2.

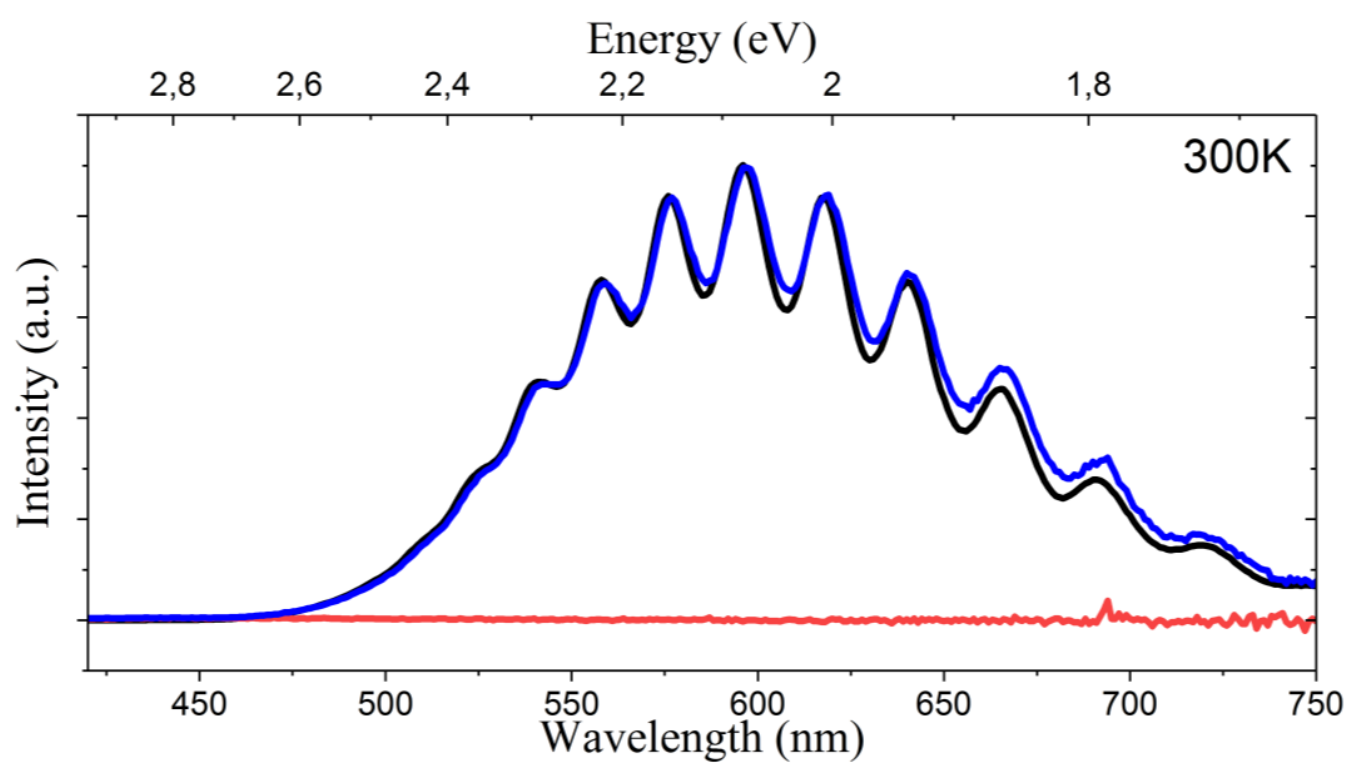

Fig. 2. Emission spectra of the N1 natural scapolite (black), and the undoped P1 (red) and sulfurdoped P2 synthetic scapolites (blue) collected at room temperature. 
Clearly, the S-free synthetic P1 sample does not give rise to detectable luminescence. At the opposite, samples P2 and N1 exhibit the same emission spectrum characterized by a wide feature ranging approximately from 475 to $730 \mathrm{~nm}$ in which a well-defined vibrational structure can be observed. This observation fully supports the facts that i) sulfur dopant is indeed responsible for the yellow-orange luminescence in scapolite, as already documented in the literature ${ }^{12}$, ii) the sulfur species is a priori the same in P2 and N1, iii) impurities in trace amounts in N1 (See Electronic Supporting Information, ESI) do not impact the optical properties. Absorption and excitation spectra of sample N1 at room temperature are given in Fig. 3.

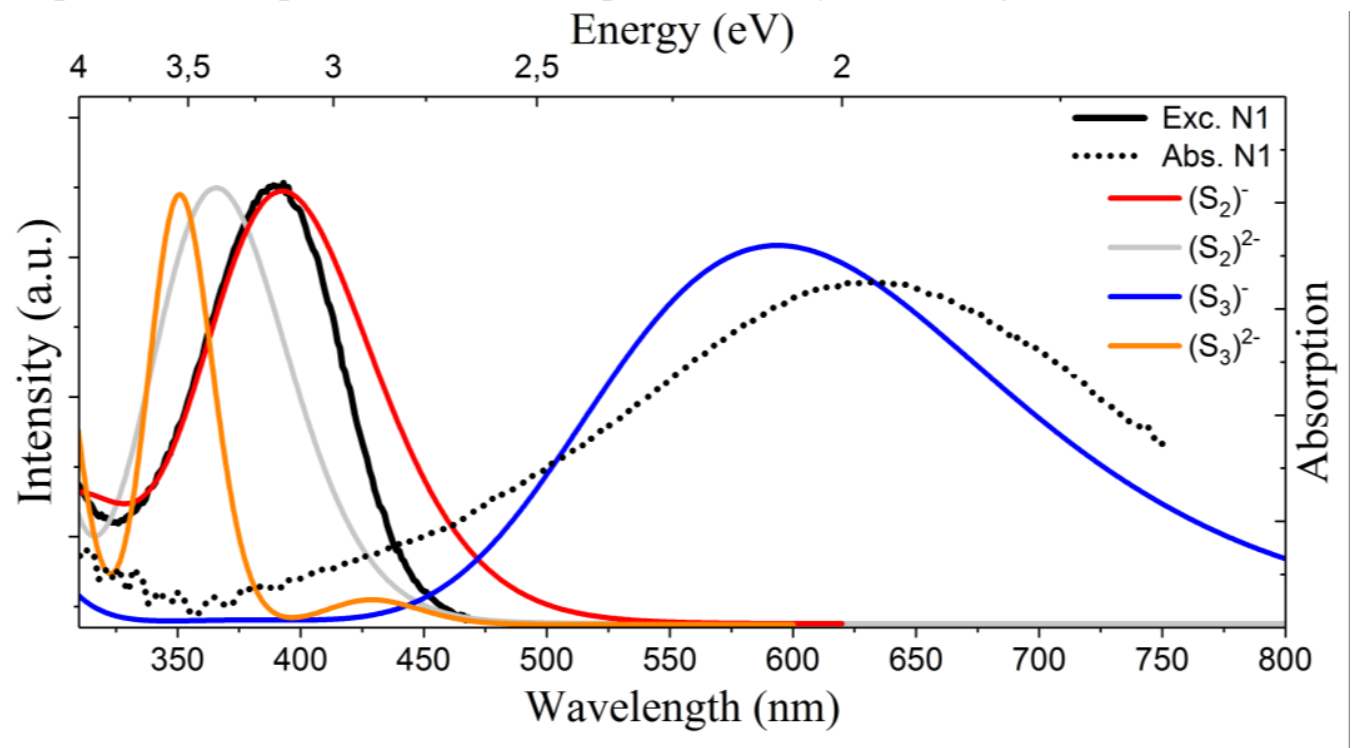

Fig.3. Experimental Kubelka-Munk transformed diffuse reflection spectrum (dotted line) and excitation spectrum (black) of $\mathrm{N} 1$ and simulation (TD-DFT) of the absorption of $\left(\mathrm{S}_{2}\right)^{-}(\mathrm{red}),\left(\mathrm{S}_{2}\right)^{2-}$ (grey), $\left(\mathrm{S}_{3}\right)^{-}$(blue) and $\left(\mathrm{S}_{3}\right)^{2-}$ (orange) species placed in the sodium cage planar environment.

The N1 excitation spectrum collected at the emission maximum shows a broad band peaking at $390 \mathrm{~nm}(3.18 \mathrm{eV})$. Another band at $285 \mathrm{~nm}(4.35 \mathrm{eV})$ has been recorded but is not presented in Fig. 3. To shed light on the absorption and excitation spectra, ab initio calculations were initiated on $\left[\mathrm{Na}_{4} \mathrm{~S}_{2}\right]^{2+},\left[\mathrm{Na}_{4} \mathrm{~S}_{2}\right]^{3+},\left[\mathrm{Na}_{4} \mathrm{~S}_{3}\right]^{2+}$ and $\left[\mathrm{Na}_{4} \mathrm{~S}_{3}\right]^{3+}$ clusters cages. To account for the interactions potentially felt by the clusters with respect to the outside atoms present in the true scapolite, a 
Polarizable Continuum Model (PCM) ${ }^{36,37}$ has been added to our simulations. Clusters have been optimized and checked to be at a minimum on the potential energy surface (frequency calculations) using the global hybrid PBE0 together with the triple- $\zeta$ Def2TZVP basis set at their ground states. ${ }^{38-40}$ All the computations have been performed using the Gaussian 16 (see ESI) suite and the post-treatments to plot spectra have been realized with the VMS package developed by Barone and co-workers. ${ }^{41}$ TD-DFT computations were performed on the relaxed ground state geometries and the related spectra are depicted in Fig. 3 for $\left(\mathrm{S}_{2}\right)^{-},\left(\mathrm{S}_{2}\right)^{2-},\left(\mathrm{S}_{3}\right)^{-}$and $\left(\mathrm{S}_{3}\right)^{2-}$ species. The excitation spectrum of $\mathrm{N} 1$ is accounted for by $\left(\mathrm{S}_{2}\right)^{-}$species. To a lesser extent $\left(\mathrm{S}_{2}\right)^{2-}$ or $\left(\mathrm{S}_{3}\right)^{2-}$ can be discarded since their absorption bands are too far away from the experimental one. It is worth mentioning that the absorption band of $\left(\mathrm{S}_{3}\right)^{-}$trimer centered at $594 \mathrm{~nm}(2.09 \mathrm{eV})$ superimposes quite well with the photo-generated absorption band at $628 \mathrm{~nm}(1.97 \mathrm{eV})$ giving the blue color to scapolite. From the emission spectrum collected at $77 \mathrm{~K}$ (Fig. 4), the separation between almost equidistant lines is determined at ca. $70 \mathrm{meV}\left(565 \mathrm{~cm}^{-1}\right)$ (see ESI) and this corresponds to a vibrational mode of the ground state of the activator. This value fits the computed one $\left(\bar{v}_{\mathrm{s}-\mathrm{s}}=580 \mathrm{~cm}^{-1}\right.$, upon a scale factor of 0.95). 


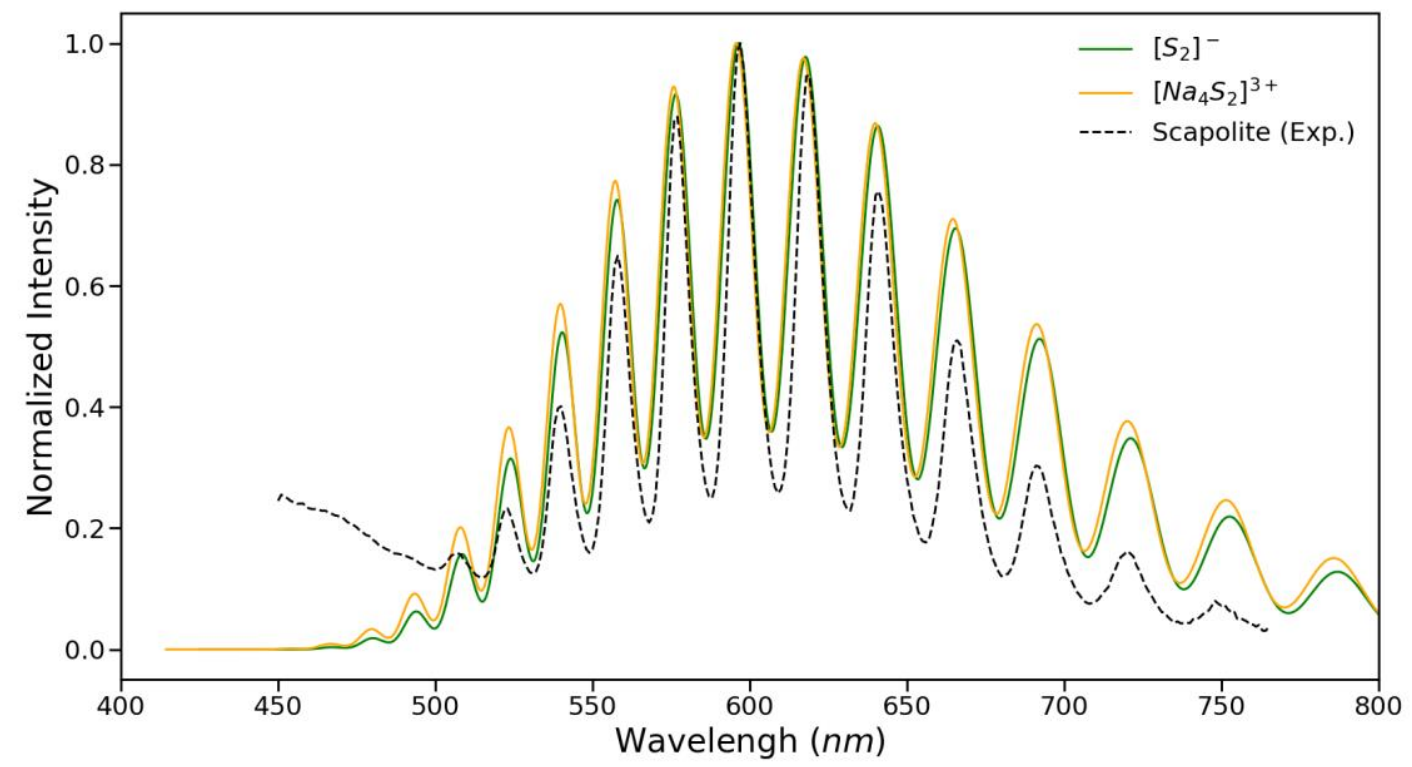

Fig.4. Experimental emission spectrum of N1 (dash black) collected at 77K and simulation of the emission of pure $\left[\mathrm{S}_{2}\right]^{-}$(green) and $\left[\mathrm{Na}_{4} \mathrm{~S}_{2}\right]^{3+}$ (orange) models. The frequency used in the vibronic calculation was $580 \mathrm{~cm}^{-1}$ for to the simulated S-S stretching. Green and orange curves were shifted to fit the experimental maximum by 1130 and $-1470 \mathrm{~cm}^{-1}$, respectively.

This specific vibration is not detectable by either Raman or infrared spectroscopies, as it is superimposed with a wide band arising from the host lattice ${ }^{42,43}$ (see ESI). Nevertheless, under the assumption of isolated $\left(\mathrm{S}_{\mathrm{n}}\right)^{\mathrm{x}-}$ polyanions, the Steudel law ${ }^{44}$ stipulates that S-S distances and S-S vibrational frequencies are linked via eq. 1 and 2 for dimers and $\left(S_{n}\right)^{x}(n>2)$, respectively.

$$
\begin{aligned}
& \mathrm{d}_{\mathrm{s}-\mathrm{s}}(\AA)=2.57-9.47 \times 10^{-4} v_{\mathrm{s}-\mathrm{s}}\left(\mathrm{cm}^{-1}\right) \text { Eq. } 1 \\
& \mathrm{~d}_{\mathrm{s}-\mathrm{s}}(\AA)=2.53-1.041 \times 10^{-3} v_{\mathrm{s}-\mathrm{s}}\left(\mathrm{cm}^{-1}\right) \text { Eq. } 2
\end{aligned}
$$

On this basis, the S-S distances associated to a vibrational frequency of $565 \mathrm{~cm}^{-1}$ would be 2.03 $\AA$ for a $\mathrm{S}_{2}$ dimer and $1.94 \AA$ for a $\mathrm{S}_{\mathrm{n}}$ oligomer with $\mathrm{n}>2$. For $\left(\mathrm{S}_{2}\right)^{\mathrm{x}}$ the distance would match satisfactorily with $\left(\mathrm{S}_{2}\right)^{-}$entities in $\mathrm{CuS}_{2}{ }^{45,46}\left(\mathrm{Cu}^{+}\left(\mathrm{S}_{2}\right)^{-} ; \mathrm{d}_{\mathrm{S}-\mathrm{S}}=2.03 \AA\right)$. By contrast regular $\left(\mathrm{S}_{2}\right)^{2-}$ pairs as observed in $\mathrm{Na}_{2} \mathrm{~S}_{2}{ }^{47}$ or $\mathrm{FeS}_{2}$ give rise to $\mathrm{S}-\mathrm{S}$ distances of about $2.15 \AA$, too long. $\left(\mathrm{S}_{2}\right)^{0}$ 
molecules have calculated distances calculated at ca. $1.90 \AA^{48}$ which is too short. For $\left(\mathrm{S}_{\mathrm{n}}\right)^{\mathrm{x}}(\mathrm{n}>2)$, the calculated distance could only be attributed to $\left(\mathrm{S}_{3}\right)^{0}$ trimers with interatomic distances of 1.92 $\AA^{49}$. The $\left(\mathrm{S}_{3}\right)^{-}$and $\left(\mathrm{S}_{3}\right)^{2-}$ entities are characterized by higher interatomic distances of $2.02 \AA,{ }^{50}$ and $2.08 \AA .^{47}$

Simulations of the luminescence properties have been performed using the Adiabatic Shift Paradigm. ${ }^{51-53}$ This approach demonstrated its accuracy when dealing with small to large rigid structures $^{54,55}$. The simulated spectra together with the experimental one are given in Fig. 4. As demonstrated, the experimental and the simulated spectrum of the $\left[\mathrm{Na}_{4} \mathrm{~S}_{2}\right]^{3+}$ and $\left[\mathrm{S}_{2}\right]^{-}$moieties are in very good agreement. Indeed, both the shape and the energy (i.e. wavelength) of the simulated spectrum nicely reproduce the experiment. On the ontrary the simulat spectum of $\left[\mathrm{Na}_{4} \mathrm{~S}_{2}\right]^{2+}$ is not comparable with the experimental one, neither in shape nor in position. Furthermore, the relaxed (ground state) S-S bond length, $10 \%$ shorter in $\left[\mathrm{Na}_{4} \mathrm{~S}_{2}\right]^{3+}(2.00 \AA)$ than in $\left[\mathrm{Na}_{4} \mathrm{~S}_{2}\right]^{2+}(2.15$ $\AA)$, demonstrates that the $\left(\mathrm{S}_{2}\right)^{-}$dimer $(2.03 \AA$ experimental distance $)$ is the most likely emission center. Further the $565 \mathrm{~cm}^{-1}$ vibronic frequency can be assigned to the S-S symmetrical stretching perpendicular to the $\left[\mathrm{Na}_{4}\right]$ cluster cage. Moreover, the analysis of the vibronic calculation demonstrates unambiguously that the nature of the vibrational pattern involves a $\mathrm{S}_{2}$ vibration. At this stage, one should mention that we were unable to stabilize any excited state of the $\left(\mathrm{S}_{3}\right)^{-}$and $\left(\mathrm{S}_{3}\right)^{2-}$ species trapped into the sodium cage to simulate their emission. Emission of $\left(\mathrm{S}_{3}\right)^{-}$, if it exists, should take place at wavelengths much higher than $600 \mathrm{~nm}$ (emission expected at lower energy than excitation) and could not be accounted for by experimental observations.

To sum up, our simulations demonstrate unambiguously that a formal $\left(\mathrm{S}_{2}\right)^{-}$anion at the center of the Na cage is favored to explain the yellow-orange luminescence properties of scapolite compared to a formal $\left(\mathrm{S}_{2}\right)^{2-}$ moiety. Within the limit of the method, simulations satisfactorily account for the 
emission peak shape and its structured features, as well as the excitation spectrum. Thus, it is now experimentally and theoretically established that the yellow-orange luminescence of scapolite is caused by a sulfur dimer perpendicular to the $\mathrm{Na}$ cage, with a formal charge of one electron $\left(\mathrm{S}_{2}\right)^{\text {- }}$. Concerning the possible coupling with the photochromic property, $\left(\mathrm{S}_{3}\right)^{-}$absorption corresponds satisfactorily with the photo-generated absorption band. Thus, inserting sulfur species capable to photo-ionize into $\left(\mathrm{S}_{3}\right)^{-}$could be a way to induce photochromism. However, $\left(\mathrm{S}_{3}\right)^{-}$has already been observed to be stable in other related aluminosilicates like lazurite ${ }^{56}$ and, to the best of our knowledge, has never been described as metastable in such materials. This assumption requires further analyses to be substantiated.

\section{Conflicts of interest}

There are no conflicts to declare.

\section{Acknowledgements}

University of Nantes made this project possible through the attribution of a doctoral contract to the first author. Dudley Blauwet from Dudley Blauwet Gems, Louisville, CO, USA, kindly donated to this project many rough samples of Afghan photochromic scapolites. Philippe Deniard, IMN-CNRS, Nantes was very instrumental with the interpretation of XRD experiments. Anette Clausen, Robert Weldon and Franck Notari are warmly thanked for their kind help to find rare articles. C.L. thanks access to the TGCC under allocation 2019-A0070911052 made by GENCI and the Centre de Calculs Intensifs des Pays de la Loire for computational ressources. During the submission process, authors learnt that a paper dedicated to the hackmanite material (not the scapolite) lead to similar results (J. Phys. Chem. C 2020, 124, 16, 8949-8957), although they were 
performed with other approximations. Author are very thankful to referees for their valuable comments during the submission.

\section{Electronic Supplementary Information}

Electronic Supplementary Information (ESI) available: DOI: 10.1039/x0xx00000x

It includes:

- Experimental details

- Computational details

- Details on natural and synthetic materials

- Characterizations technics

\section{Notes and references}

(1) Depmeier, W. From Minerals to Materials. In Minerals as Advanced Materials II; Krivovichev, S. V., Ed.; Berlin Heidelberg, 2012; pp 1-11.

(2) Sanders, J. V. Diffraction of Light by Opals. Acta Crystallogr. Sect. A 1968, 24 (4), $427-$ 434. https://doi.org/10.1107/S0567739468000860.

(3) Chang, I. F. Synthesis of Photochromic and Cathodochromic Sodalite. J. Electrochem. Soc. 1974, 121 (6), 815-820. https://doi.org/10.1149/1.2401925.

(4) Chapman, G. N.; Walton, A. J. Triboluminescence of Fluorites. J. Phys. C Solid State Phys. 1983, 16 (28), 5543-5551. https://doi.org/10.1088/0022-3719/16/28/021. 
(5) Ogundare, F. O.; Balogun, F. A.; Hussain, L. A. Kinetic Characterization of the Thermoluminescence of Natural Fluorite. Radiat. Meas. 2004, 38 (3), 281-286. https://doi.org/10.1016/j.radmeas.2003.11.007.

(6) Ogundare, F. O.; Balogun, F. A.; Hussain, L. A. Heating Rate Effects on the Thermoluminescence of Fluorite. Radiat. Meas. 2005, 40 (1), 60-64. https://doi.org/10.1016/j.radmeas.2005.01.004.

(7) Norrbo, I.; Gluchowski, P.; Paturi, P.; Sinkkonen, J.; Lastusaari, M. Persistent Luminescence of Tenebrescent $\mathrm{Na}_{8} \mathrm{Al}_{6} \mathrm{Si}_{6} \mathrm{O}_{24}(\mathrm{Cl}, \mathrm{S})_{2}$ : Multifunctional Optical Markers. Inorg. Chem. 2015, 54 (16), 7717-7724. https://doi.org/10.1021/acs.inorgchem.5b00568.

(8) Norrbo, I.; Gluchowski, P.; Hyppänen, I.; Laihinen, T.; Laukkanen, P.; Mäkelä, J.; Mamedov, F.; Santos, H. S.; Sinkkonen, J.; Tuomisto, M.; Viinikanoja, A.; Lastusaari, M. Mechanisms of Tenebrescence and Persistent Luminescence in Synthetic Hackmanite $\mathrm{Na}_{8} \mathrm{Al}_{6} \mathrm{Si}_{6} \mathrm{O}_{24}(\mathrm{Cl}, \mathrm{S})_{2}$. ACS Appl. Mater. Interfaces 2016, 8 (18), 11592-11602. https://doi.org/10.1021/acsami.6b01959.

(9) Medved, D. B. The Optical Properties of Natural and Synthetic Hackmanite. J. Chem. Phys. 1953, 21 (7), 1309-1310. https://doi.org/10.1063/1.1699204.

(10) Kirk, R. D. The Luminescence and Tenebrescence Of. Am. Mineral. 1955, 40 (1-2), 22-31.

(11) McClure, S. F.; Rossman, G. R.; Shigley, J. E. Tenebrescent Scapolite from Afghanistan. Gems Gemol. 2005, 41 (Fall), 269-271.

(12) Burgner, R. P.; Scheetz, B. E.; White, W. B. Vibrational Structure of the $\mathrm{S}_{2}^{-}$Luminescence in Scapolite. Phys. Chem. Miner. 1978, 2, 317-324. https://doi.org/10.1007/BF00307574.

(13) Schulman, J. H.; Kirk, R. D. Luminescent Sulfur Centers in Alkali Halides and Other Inorganic Solids. Solid State Commun. 1964, 2, 105-108. 
(14) Kirk, R. D. Role of Sulfur in the Luminescence and Coloration of Some Aluminosilicates. J. Electrochem. Soc. 1954, 101 (9), 461-465.

(15) Sidike, A.; Kusachi, I.; Kobayashi, S.; Atobe, K.; Yamashita, N. Photoluminescence Spectra of $\mathrm{S}_{2}{ }^{-}$Center in Natural and Heat-Treated Scapolites. Physics and Chemistry of Minerals. 2008, pp 137-145. https://doi.org/10.1007/s00269-007-0205-3.

(16) Chang, I. F.; Onton, A. Optical Properties of Photochromatic Sulfur-Doped Chlorosodalite. J. Electron. Mater. 1973, 2 (1), 17-46. https://doi.org/10.1007/BF02658102.

(17) Gaft, M.; Panczer, G.; Nagli, L.; Yeates, H. Laser-Induced Time-Resolved Luminescence of Tugtupite, Sodalite and Hackmanite. Phys. Chem. Miner. 2009, 36 (3), 127-141. https://doi.org/10.1007/s00269-008-0263-1.

(18) Ruivo, A.; Coutino-Gonzalez, E.; Santos, M. M.; Baekelant, W.; Fron, E.; Roeffaers, M. B. J.; Pina, F.; Hofkens, J.; Laia, C. A. T. Highly Photoluminescent Sulfide Clusters Confined in Zeolites. J. Phys. Chem. C 2018, 122 (26), 14761-14770. https://doi.org/10.1021/acs.jpcc.8b01247.

(19) Clark, R. J. H.; Cobbold, D. G. Characterization of Sulfur Radical Anions in Solutions of Alkali Polysulfides in Dimethylformamide and Hexamethylphosphoramide and in the Solid State in Ultramarine Blue, Green, and Red. Inorg. Chem. 1978, 17 (11), 3169-3174. https://doi.org/10.1021/ic50189a042.

(20) Ye, R.; Tazawa, H.; Baba, M.; Nishidate, K.; Schwan, L. O.; Schmid, D. Formation of an S2- Molecular Ion and Its Luminescence Characteristics in KCl:MnS Crystals. Japanese J. Appl. Physics, Part 2 Lett. 1998, 37 (10 PART A), 8-12.

(21) Rolfe, J. Emission Spectra of $\mathrm{S}_{2}^{-}, \mathrm{Se}_{2}{ }^{-}$, and $\mathrm{SeS}^{-}$Ions in KI Crystals. J. Chem. Phys. 1968, 49 (9), 4193-4197. https://doi.org/10.1063/1.1670735. 
(22) Ikezawa, M.; Rolfe, J. Zero-Phonon Transitions in $\mathrm{O}_{2}^{-}, \mathrm{S}_{2}^{-}, \mathrm{Se}_{2}^{-}$, and $\mathrm{SeS}^{-}$Molecules Dissolved in Alkali Halide Crystals. J. Chem. Phys. 1973, 58 (5), 2024-2038. https://doi.org/10.1063/1.1679466.

(23) Holzer, W.; Murphy, W. F.; Bernstein, H. J. Raman Spectra of Negative Molecular Ions Doped in Alkali Halide Crystals. J. Mol. Spectrosc. 1969, 32 (1), 13-23. https://doi.org/10.1016/0022-2852(69)90139-8.

(24) Shaw, D. The Geochemistry of Scapolite, Part I. Previous Work and General Mineralogy. J. Petrol. 1960, 1 (2), 218-260.

(25) Lin, S. B.; Burley, B. J. Crystal Structure of a Sodium and Chlorine-Rich Scapolite. Acta Crystallogr. 1973, B29 (7), 1272-1278.

(26) Lin, S. B.; Burley, B. J. The Crystal Structure of Meionite. Acta Crystallogr. Sect. B 1973, 29, 2024-2026.

(27) Sokolova, E.; Hawthorne, F. C. The Crystal Chemistry of the Scapolite-Group Minerals. I. Crystals Structure and Long-Range Order. Can. Mineral. 2008, 46 (6), 1527-1554. https://doi.org/10.3749/canmin.46.6.1527.

(28) Haberlandt, H. Fluoreszenzanalyse von Mineralien; Akad. d. Wiss., 1934.

(29) Haberlandt, H. Neue Lumineszenzuntersuchungen an Fluoriten Und Anderen Mineralien IV . In Akademie der Wissenschaften Wien; 1949; Vol. 143.

(30) Currie, D.; Jaszczyn-Kopec, P.; Liu, H. K.; Berry, D.; Williams, F. The Effect of Hydrostatic and Uniaxial Pressures on Vibronic Spectra. J. Lumin. 1981, 24/25, 145-154. https://doi.org/10.1119/1.1970309.

(31) Curutchet, A.; Le Bahers, T. Modeling the Photochromism of S-Doped Sodalites Using DFT, TD-DFT, and SAC-CI Methods. Inorg. Chem. 2017, 56 (1), 414-423. 
https://doi.org/10.1021/acs.inorgchem.6b02323.

(32) Norrbo, I.; Curutchet, A.; Kuusisto, A.; Mäkelä, J.; Laukkanen, P.; Paturi, P.; Laihinen, T.; Sinkkonen, J.; Wetterskog, E.; Mamedov, F.; Le Bahers, T.; Lastusaari, M. Solar UV Index and UV Dose Determination with Photochromic Hackmanites: From the Assessment of the Fundamental Properties to the Device. Mater. Horizons 2018, 5 (3), 569-576. https://doi.org/10.1039/c8mh00308d.

(33) Zahoransky, T.; Friis, H.; Marks, M. A. W. Luminescence and Tenebrescence of Natural Sodalites: A Chemical and Structural Study. Phys. Chem. Miner. 2016, 43 (7), 459-480. https://doi.org/10.1007/s00269-016-0810-0.

(34) Almeida, K. M. F.; Jenkins, D. M. Stability Field of the Cl-Rich Scapolite Marialite. Am. Mineral. 2017, 102 (12), 2484-2493. https://doi.org/10.2138/am-2017-6132.

(35) Morizet, Y.; Brooker, R. A.; Kohn, S. C. $\mathrm{CO}_{2}$ in Haplo-Phonolite Melt: Solubility, Speciation and Carbonate Complexation. Geochim. Cosmochim. Acta 2002, 66 (10), 18091820. https://doi.org/10.1016/S0016-7037(01)00893-6.

(36) Barone, V.; Cossi, M.; Tomasi, J. A New Definition of Cavities for the Computation of Solvation Free Energies by the Polarizable Continuum Model. J. Chem. Phys. 1997, 107 (8), 3210. https://doi.org/10.1063/1.474671.

(37) Cossi, M.; Scalmani, G.; Rega, N.; Barone, V. New Developments in the Polarizable Continuum Model for Quantum Mechanical and Classical Calculations on Molecules in Solution. J. Chem. Phys. 2002, 117 (1), 43. https://doi.org/10.1063/1.1480445.

(38) Adamo, C.; Barone, V. Toward Reliable Density Functional Methods without Adjustable Parameters: The PBE0 Model. J. Chem. Phys. 1999, 110 (13), 6158-6170. https://doi.org/10.1063/1.478522. 
(39) Ernzerhof, M.; Scuseria, G. E. Assessment of the Perdew-Burke-Ernzerhof ExchangeCorrelation Functional. J. Chem. Phys. 1999, 110 (11), 5029-5036. https://doi.org/10.1063/1.478401.

(40) Weigend, F.; Ahlrichs, R. Balanced Basis Sets of Split Valence\{,\} Triple Zeta Valence and Quadruple Zeta Valence Quality for H to Rn: Design and Assessment of Accuracy. Phys. Chem. Chem. Phys. 2005, 7 (18), 3297-3305. https://doi.org/10.1039/B508541A.

(41) Licari, D.; Baiardi, A.; Biczysko, M.; Egidi, F.; Latouche, C.; Barone, V. Implementation of a Graphical User Interface for the Virtual Multifrequency Spectrometer: The VMS-Draw Tool. J. Comput. Chem. 2015, 36 (5), 321-334.

(42) Culka, A.; Hyršl, J.; Jehlička, J. Gem and Mineral Identification Using GL Gem Raman and Comparison with Other Portable Instruments. Appl. Phys. A Mater. Sci. Process. 2016, 122 (11). https://doi.org/10.1007/s00339-016-0500-2.

(43) Swayze, G.; Clark, R. Infrared Spectra and Crystal Chemistry of Scapolites - Implications for Martian Mineralogy. J. Geophys. Res. 1990, 95 (B9), 14481-14495.

(44) Steudel, R. Properties of Sulfur-Sulfur Bonds. Angew. Chemie - Int. Ed. 1975, 14 (10), 655664.

(45) King, H. E.; Prewitt, C. T. Structure and Symmetry of $\mathrm{CuS}_{2}$ (Pyrite Structure). Am. Mineral. 1979, $64(11-12), 1265-1271$.

(46) Jobic, S.; Brec, R.; Rouxel, J. Occurrence and Characterization of Anionic Bondings in Transition Metal Dichalcogenides. J. Alloys Compd. 1992, 178 (1-2), 253-283. https://doi.org/10.1016/0925-8388(92)90269-F.

(47) El Jaroudi, O.; Picquenard, E.; Demortier, A.; Lelieur, J. P.; Corset, J. Polysulfide Anions II: Structure and Vibrational Spectra of the $\left(\mathrm{S}_{4}\right)^{2-}$ and $\left(\mathrm{S}_{5}\right)^{2-}$ Anions. Influence of the Cations 
on Bond Length, Valence, and Torsion Angle. Inorg. Chem. 2000, 39 (12), 2593-2603. https://doi.org/10.1021/ic991419x.

(48) Wang, X.; Liang, B.; Andrews, L. Infrared Spectra and Density Functional Theory Calculations of Coinage Metal Disulfide Molecules and Complexes. Dalt. Trans. 2009, 21, 4190-4198. https://doi.org/10.1039/b902115a.

(49) McCarthy, M. C.; Thorwirth, S.; Gottlieb, C. A.; Thaddeus, P. The Rotational Spectrum and Geometrical Structure of Thiozone, S3. J. Am. Chem. Soc. 2004, 126 (13), 4096-4097. https://doi.org/10.1021/ja049645f.

(50) Tossell, J. A. Calculation of the Properties of the $\mathrm{S}_{3}{ }^{-}$Radical Anion and Its Complexes with $\mathrm{Cu}^{+}$in Aqueous Solution. Geochim. Cosmochim. Acta 2012, 95, 79-92. https://doi.org/10.1016/j.gca.2012.07.020.

(51) Barone, V.; Baiardi, A.; Biczysko, M.; Bloino, J.; Cappelli, C.; Lipparini, F. Implementation and Validation of a Multi-Purpose Virtual Spectrometer for Large Systems in Complex Environments. Phys. Chem. Chem. Phys. 2012, 14 (36), 12404-12422. https://doi.org/10.1039/C2CP41006K.

(52) Barone, V.; Bloino, J.; Biczysko, M.; Santoro, F. Fully Integrated Approach to Compute Vibrationally Resolved Optical Spectra: From Small Molecules to Macrosystems. J. Chem. Theory Comput. 2009, 5 (3), 540-554. https://doi.org/10.1021/ct8004744.

(53) Vazart, F.; Latouche, C.; Bloino, J.; Barone, V. Vibronic Coupling Investigation to Compute Phosphorescence Spectra of Pt(II) Complexes. Inorg. Chem. 2015, 54 (11), 55885595. https://doi.org/10.1021/acs.inorgchem.5b00734.

(54) Belaidi, H.; Belaidi, S.; Katan, C.; Latouche, C.; Boucekkine, A. Vibronic Coupling to Simulate the Phosphorescence Spectra of Ir(III)-Based OLED Systems: TD-DFT Results 
Meet Experimental Data. J. Mol. Model. 2016, $22 \quad$ (11), 265. https://doi.org/10.1007/s00894-016-3132-8.

(55) Latouche, C.; Baiardi, A.; Barone, V. Virtual Eyes Designed for Quantitative Spectroscopy of Inorganic Complexes: Vibronic Signatures in the Phosphorescence Spectra of Terpyridine Derivatives. J. Phys. Chem. B 2015, 119 (24), 7253-7257. https://doi.org/10.1021/jp510589u.

(56) Tauson, V. L.; Goettlicher, J.; Sapozhnikov, A. N.; Mangold, S.; Lustenberg, E. E. Sulphur Speciation in Lazurite-Type Minerals $(\mathrm{Na}, \mathrm{Ca})_{8}\left[\mathrm{Al}_{6} \mathrm{Si}_{6} \mathrm{O}_{24}\right]\left(\mathrm{SO}_{4}, \mathrm{~S}\right)_{2}$ and Their Annealing Products: A Comparative XPS and XAS Study. Eur. J. Mineral. 2012, 24 (1), 133-152. https://doi.org/10.1127/0935-1221/2011/0023-2132. 